\title{
Effects of age, gender and region on serum concentrations of perfluorinated compounds in general population of Henan, China
}

\author{
Yaning Fu ${ }^{\mathrm{a}, \mathrm{b}}$, Tieyu Wang ${ }^{\mathrm{a}}$, Pei Wang ${ }^{\mathrm{a}, \mathrm{b}}$, Quanliang Fu ${ }^{\mathrm{c}}$, Yonglong Lu ${ }^{\mathrm{a}, *}$ \\ a State Key Lab of Urban and Regional Ecology, Research Center for Eco-Environmental Sciences, Chinese Academy of Sciences, Beijing 100085, China \\ ${ }^{\mathrm{b}}$ University of Chinese Academy of Sciences, Beijing 100049, China \\ ${ }^{\mathrm{c}}$ Red Cross Hospital of Yuanyang, Yuanyang County, Henan 453500, China
}

\section{H I G H L I G H T S}

- 133 Serum samples were collected from inland China aged 0-88 years for analysis.

- Compared with coastal region, the levels and composition of PFCs were different.

- Significant increases in PFOA, PFNA, and PFOS concentrations over age were found.

- Median concentrations of 4 PFCs were higher in males than in females.

- Higher PFOA concentrations were found in urban populations.

\section{A R T I C L E I N F O}

\section{Article history:}

Received 16 April 2013

Received in revised form 27 January 2014

Accepted 6 February 2014

Available online 13 March 2014

Handling Editor: H. Fiedler

\section{Keywords:}

Perfluorinated compound

Serum

General population

Henan

\begin{abstract}
A B S T R A C T
133 Serum samples collected from Henan donors aged from 0 to 88 years were analyzed for 12 perfluorinated compounds (PFCs). Perfluorooctanoic acid (PFOA) and perfluorooctane sulfonate (PFOS) accounted for $69.19 \%$ of the total PFCs in serum samples, with a median concentration of 1.43 and $1.47 \mathrm{ng} \mathrm{mL}{ }^{-1}$, respectively. Other PFCs were detected at much lower concentrations, with median concentrations ranging from 0.03 to $0.37 \mathrm{ng} \mathrm{mL}^{-1}$. PFOA and PFOS were positively correlated $(r=0.219)$ in serum samples, indicating that they may have common exposure pathways. For all donors ( $0-88$ years), significant increases in PFOA $(r=0.239, p<0.01)$, perfluorononanoic acid (PFNA) $(r=0.185, p<0.05)$ and PFOS $(r=0.175, p<0.05)$ concentrations over age were found. Median concentrations of PFOA, PFNA, perfluorodecanoic acid (PFDA), and PFOS were higher in males than in females. Higher PFOA concentrations were found in urban populations than in rural populations. Since PFCs exposure in general population is prevalent, further studies are needed to explore its possible impacts on epidemiological factors.
\end{abstract}

(c) 2014 Elsevier Ltd. All rights reserved.

\section{Introduction}

Perfluorinated compounds (PFCs) are a group of manmade chemicals with surface-active properties, which have been widely used as surfactants and surface protectors in lubricants, paints, polishes, fire-fighting foams, food packaging and many other applications for over 50 years (Lau et al., 2007). In recent years, PFCs have drawn great concerns internationally due to their global occurrences in environment and biota (Giesy and Kannan, 2001; Meesters and Schroder, 2004), as well as their toxicity (Lau et al., 2007) and bioaccumulation (Martin et al., 2004). PFCs have also been found in food (Tittlemier et al., 2006), drinking water (Skutlarek et al., 2006), indoor air and dust (Shoeib et al., 2005), which

\footnotetext{
* Corresponding author. Tel.: +86 10 62849466; fax: +86 1062918177 .

E-mail address: yllu@rcees.ac.cn (Y. Lu).
}

are potential human exposure pathways and raise concerns over human health.

PFCs have been found in human blood or serum samples in general population from many countries (Kannan et al., 2004; Fromme et al., 2009), including China (So et al., 2006; Pan et al., 2010). In the meantime, relationships between age, gender and PFCs concentrations have been discussed in a few studies. However, previous studies are controversial about the age and gender effects on PFCs concentrations in general population (Karrman et al., 2006; Zhang et al., 2010b). Furthermore, while most of the previous studies focused on coastal and industrialized areas, where lifestyles are very different with inland areas, studies focusing on inland and agricultural areas are needed.

Henan, with a population of over 94 million, is a major agricultural province located in the central part of China. Henan is the 5th largest provincial economy of China and the largest among inland 
provinces. However, as a semi-industrialized economy, per capita GDP of Henan is low compared to eastern provinces, and Henan is considered to be one of the most backward areas of China. Agriculture has traditionally been a pillar of its economy, with the nation's highest wheat output and second highest rice output, earning its reputation as the breadbasket of China. Unlike the coastal region where diet is high in fish, the diet in this region relies mainly on grain, vegetable, meat, poultry and egg. In the present study, the concentrations of 12 PFCs in 133 serum samples derived from a general population of Henan were analyzed. The aim of this study is to evaluate the PFCs concentrations in general populations in inland and agricultural area, as well as effects of age, gender and region on PFCs concentrations.

\section{Materials and methods}

\subsection{Sampling}

During October-November 2011, 133 serum samples derived from individuals living in Yuanyang County (Henan, China) were obtained from the Yuanyang Red Cross Hospital. The participants aged from 0 to 88 years old were divided into five age groups ( 0 15 years, $16-30$ years, $31-45$ years, $45-60$ years, 61 years and older), two gender groups ( 79 males and 54 females) and two region groups (33 from urban area and 100 from rural areas), separately. Whole blood of approximate $5 \mathrm{~mL}$ was withdrawn from each donor, and the serum was immediately separated. Serum samples were stored at $-20^{\circ} \mathrm{C}$ until analysis.

Information on lifestyle and demographic factors was collected through interviews. In the present study, body mass index (BMI), per capita net income, consumptions of meat, egg, fish and seafood were examined as potential determinants on serum PFCs concentrations.

\subsection{PFCs analyses}

Serum samples were analyzed for 12 PFCs, including perfluorobutane sulfonate (PFBS), perfluorohexane sulfonate (PFHXS), perfluorooctane sulfonate (PFOS), perfluorobutyric acid (PFBA), perfluoropentanoic acid (PFPeA), perfluorohexanoic acid (PFHxA), perfluoroheptanoic acid (PFHpA), perfluorooctanoic acid (PFOA), perfluorononanoic acid (PFNA), perfluorodecanoic acid (PFDA), perfluoroundecanoic acid (PFUdA) and perfluorododecanoic acid (PFDoA). The external standard used for all matrix spikes was a mixture of 12 PFCs (>98\%) purchased from Wellington Laboratories (Guelph, Ontario, Canada). The mixture of 9 isotope-labeled internal standards $\left({ }^{18} \mathrm{O}_{2}\right.$-labeled PFHxS, ${ }^{13} \mathrm{C}_{4}$-labeled PFOS, ${ }^{13} \mathrm{C}_{4}$-labeled PFBA, ${ }^{13} \mathrm{C}_{2}$-labeled PFHxA, ${ }^{13} \mathrm{C}_{4}$-labeled PFOA, ${ }^{13} \mathrm{C}_{5}$-labeled PFNA, ${ }^{13} \mathrm{C}_{2}$-labeled PFDA, ${ }^{13} \mathrm{C}_{2}$-labeled PFUdA and ${ }^{13} \mathrm{C}_{2}$-labeled PFDoA) was also obtained from Wellington Laboratories.

Serum samples were prepared according to the methods outlined in Hansen et al., 2001, with minor modifications. Briefly, $0.5 \mathrm{~mL}$ of serum, $100 \mu \mathrm{L}$ labeled internal standards $\left(10 \mathrm{ng} \mathrm{mL}^{-1}\right)$, $2 \mathrm{~mL}$ of sodium carbonate $\left(\mathrm{Na}_{2} \mathrm{CO}_{3}\right)\left(0.25 \mathrm{~mol} \mathrm{~L}^{-1}\right)$, and $1 \mathrm{~mL}$ of tetrabutylammonium hydrogen sulfate (TBAHS) $\left(0.5 \mathrm{~mol} \mathrm{~L}^{-1}\right)$ were added to a $15 \mathrm{~mL}$ clean polypropylene (PP) tube for extraction and mixed well. $5 \mathrm{~mL}$ methyl tert-butyl ether (MTBE) was then added to the solution, and the mixture was shaken for $20 \mathrm{~min}$ The organic and aqueous layers were separated by centrifugation at $2160 \times \mathrm{g}$ for $15 \mathrm{~min}$, and the organic layer was transferred to a second polypropylene tube. The aqueous layer was then extracted twice with MTBE, and the organic layer was separated and combined with that from the first extraction. The combined MTBE extracts were evaporated to dryness under high purity nitrogen, and then the residue was reconstituted in $1 \mathrm{~mL}$ of a mixture of methanol and $10 \mathrm{mmol} \mathrm{L}^{-1}$ ammonium acetate (2:3, v/v). Finally, the sample was filtered through a $0.22 \mu \mathrm{m}$ nylon filter.

PFCs were analyzed as outlined in Bao et al. (2011) using high performance liquid chromatography-tandem mass spectrometry (HPLC-MS/MS). Chromatography was performed by an Agilent 1290 HPLC system (Palo Alto, CA, USA). A $10 \mu \mathrm{L}$ aliquot of extract was injected onto a $2.1 \times 100 \mathrm{~mm}(3.5 \mu \mathrm{m})$ Agilent Eclipse Plus C18 column (Palo Alto, CA, USA) with $10 \mathrm{mmol} \mathrm{L}^{-1}$ ammonium acetate and acetonitrile as mobile phases starting with $30 \%$ acetonitrile at a flow rate of $0.3 \mathrm{~mL} \mathrm{~min}^{-1}$ and column temperature of $40{ }^{\circ} \mathrm{C}$. The gradient was increased to $90 \%$ acetonitrile at 9 min and then held for $2 \mathrm{~min}$. In addition, an $8 \mathrm{~min}$ re-equilibration interval was run before each following sample. The HPLC system was interfaced to an Agilent 6460 Triple Quadrupole (QQQ) mass spectrometer (Santa Clara, CA, USA) operated with electro spray ionization (ESA) in negative mode. The gas temperature and ion spray voltage were maintained at $350{ }^{\circ} \mathrm{C}$ and $4000 \mathrm{~V}$. Ions were monitored with a multiple reaction monitoring (MRM) mode. The MS/MS transition for each target analyte, the applied collision energy, and the fragmentation voltage are summarized in Supplementary Table S1.

\subsection{Quality assurance and quality control}

Procedural blanks were prepared at an interval of every ten samples to check if contamination occurred during the extraction of serum samples. Solvent blanks containing acetonitrile and Milli-Q water $(2: 3, \mathrm{v} / \mathrm{v})$ were prepared to run after every twenty samples to monitor for background contamination. Duplicate injections and calibration check standards were run after every twenty samples to assure the precision and accuracy of each run. The concentrations of serum extracts were quantified via ninepoint matrix-matched calibration curves ranging from 0.01 to $100 \mathrm{ng} \mathrm{mL}^{-1}$ which were performed by adding mixed PFC standard solution into blank newborn bovine serum. The regression coefficients $\left(r^{2}\right)$ of calibration curves for all the target analytes were higher than 0.99. The limit of detection (LOD) was defined as three-fold larger than the signal-to-noise ratio, and the limit of quantification (LOQ) was defined as ten-fold larger than the signal-to-noise ratio. The recovery and reproducibility of the serum sample extraction were determined on six replicate analyses of $0.5 \mathrm{~mL}$ of newborn bovine serum containing $2 \mathrm{ng}$ of each PFC standard. No PFC contamination was found above the LOD in newborn bovine serum. The LOD, LOQ and matrix spike recoveries for all the target chemicals are summarized in Supplementary Table S1.

\subsection{Statistical analysis}

Statistical analyses were conducted using SPSS Statistics v19.0. Only PFCs that were detected in more than $75 \%$ of the samples were used for statistical analyses. Non-detects was included in the calculation, as a proxy value of an LOD/2. The Spearman rank correlation analyses were employed to examine the relationship between age and PFCs concentrations, and among various PFCs in the samples. Mann-Whitney $U$-tests were used to assess the effects of gender and region on PFCs concentrations in serum. Linear regression analyses were used to evaluate the effects of possible determinants on serum PFCs concentrations. PFCs concentrations were natural $\log$ transformed to satisfy the criteria of normality.

\section{Results and discussion}

\subsection{PFCs in human serum}

Serum concentrations of 12 PFCs, stratified by the characteristics of the study population are given in Table 1. PFBA (78.20\%), 
Table 1

Serum perfluorinated compounds concentrations $\left(\mathrm{ng} \mathrm{mL}^{-1}\right)$ in general population of Henan by natural features of the study population.

\begin{tabular}{|c|c|c|c|c|c|c|c|c|c|c|c|c|c|c|}
\hline Variable & $\mathrm{N}(\%)$ & PFBA & PFPeA & PFHxA & PFHpA & PFOA & PFNA & PFDA & PFUdA & PFDoA & PFBS & PFHxS & PFOS & $\sum \mathrm{PFCs}$ \\
\hline All samples & $\begin{array}{l}133 \\
(100.00 \%)\end{array}$ & $\begin{array}{l}0.11 \\
(0.01-0.65)\end{array}$ & $\begin{array}{l}0.03 \\
(0.01-0.09)\end{array}$ & $\begin{array}{l}0.03 \\
(0.01-0.32)\end{array}$ & $\begin{array}{l}0.04 \\
(0.01-0.29)\end{array}$ & $\begin{array}{l}1.43 \\
(0.32-39.46)\end{array}$ & $\begin{array}{l}0.37 \\
(0.02-4.68)\end{array}$ & $\begin{array}{l}0.19 \\
(0.02-2.16)\end{array}$ & $\begin{array}{l}0.26 \\
(0.02-1.93)\end{array}$ & $\begin{array}{l}0.03 \\
(0.03-1.71)\end{array}$ & $\begin{array}{l}0.03 \\
(0.03-2.23)\end{array}$ & $\begin{array}{l}0.05 \\
(0.05-1.74)\end{array}$ & $\begin{array}{l}1.47 \\
(0.08-10.20)\end{array}$ & $\begin{array}{l}5.40 \\
(1.60-45.25)\end{array}$ \\
\hline \%sum & & $2.26 \%$ & $0.44 \%$ & $0.61 \%$ & $0.72 \%$ & $44.06 \%$ & $8.30 \%$ & $4.55 \%$ & $5.13 \%$ & $3.19 \%$ & $2.89 \%$ & $2.71 \%$ & $25.13 \%$ & $100 \%$ \\
\hline LOD & & 0.02 & 0.02 & 0.02 & 0.02 & 0.02 & 0.04 & 0.04 & 0.04 & 0.05 & 0.05 & 0.10 & 0.05 & \\
\hline $\mathrm{N}>\operatorname{LOD}(\%)$ & & 104 (78.20\%) & 85 (63.91\%) & $102(76.69 \%)$ & 131 (98.50\%) & $133(100.00 \%)$ & 130 (97.74\%) & $110(82.71 \%)$ & $108(81.20 \%)$ & 46 (34.59\%) & $40(30.08 \%)$ & 35 (26.32\%) & 133 (100.00\%) & 133 (100.00\%) \\
\hline \multicolumn{15}{|l|}{ Age (years) } \\
\hline $0-15$ & $\begin{array}{l}44 \\
(33.08 \%)\end{array}$ & $\begin{array}{l}0.11 \\
(0.01-0.65)\end{array}$ & $\begin{array}{l}0.03 \\
(0.01-0.07)\end{array}$ & $\begin{array}{l}0.04 \\
(0.01-0.32)\end{array}$ & $\begin{array}{l}0.05 \\
(0.01-0.29)\end{array}$ & $\begin{array}{l}1.20 \\
(0.38-39.46)\end{array}$ & $\begin{array}{l}0.32 \\
(0.04-4.68)\end{array}$ & $\begin{array}{l}0.17 \\
(0.02-1.66)\end{array}$ & $\begin{array}{l}0.25 \\
(0.02-1.91)\end{array}$ & $\begin{array}{l}0.03 \\
(0.03-1.71)\end{array}$ & $\begin{array}{l}0.03 \\
(0.03-2.23)\end{array}$ & $\begin{array}{l}0.05 \\
(0.05-0.76)\end{array}$ & $\begin{array}{l}1.35 \\
(0.22-3.35)\end{array}$ & $\begin{array}{l}5.32 \\
(1.74-45.25)\end{array}$ \\
\hline $16-30$ & $\begin{array}{l}24 \\
(18.05 \%)\end{array}$ & $\begin{array}{l}0.10 \\
(0.01-0.65)\end{array}$ & $\begin{array}{l}0.03 \\
(0.01-0.06)\end{array}$ & $\begin{array}{l}0.03 \\
(0.01-0.09)\end{array}$ & $\begin{array}{l}0.04 \\
(0.01-0.11)\end{array}$ & $\begin{array}{l}1.20 \\
(0.60-19.77)\end{array}$ & $\begin{array}{l}0.23 \\
(0.02-2.78)\end{array}$ & $\begin{array}{l}0.19 \\
(0.02-1.62)\end{array}$ & $\begin{array}{l}0.24 \\
(0.02-1.44)\end{array}$ & $\begin{array}{l}0.03 \\
(0.03-1.24)\end{array}$ & $\begin{array}{l}0.03 \\
(0.03-0.36)\end{array}$ & $\begin{array}{l}0.05 \\
(0.05-1.31)\end{array}$ & $\begin{array}{l}1.31 \\
(0.34-2.15)\end{array}$ & $\begin{array}{l}4.11 \\
(1.60-24.66)\end{array}$ \\
\hline $31-45$ & $\begin{array}{l}15 \\
(11.28 \%)\end{array}$ & $\begin{array}{l}0.05 \\
(0.01-0.40)\end{array}$ & $\begin{array}{l}0.03 \\
(0.01-0.09)\end{array}$ & $\begin{array}{l}0.03 \\
(0.01-0.08)\end{array}$ & $\begin{array}{l}0.04 \\
(0.03-0.08)\end{array}$ & $\begin{array}{l}1.98 \\
(0.59-17.09)\end{array}$ & $\begin{array}{l}0.36 \\
(0.02-1.28)\end{array}$ & $\begin{array}{l}0.19 \\
(0.05-1.65)\end{array}$ & $\begin{array}{l}0.27 \\
(0.08-0.95)\end{array}$ & $\begin{array}{l}0.03 \\
(0.03-0.90)\end{array}$ & $\begin{array}{l}0.03 \\
(0.03-1.09)\end{array}$ & $\begin{array}{l}0.05 \\
(0.05-1.74)\end{array}$ & $\begin{array}{l}1.96 \\
(0.48-5.88)\end{array}$ & $\begin{array}{l}7.70 \\
(2.82-22.64)\end{array}$ \\
\hline $46-60$ & $\begin{array}{l}32 \\
(24.06 \%)\end{array}$ & $\begin{array}{l}0.13 \\
(0.01-0.53)\end{array}$ & $\begin{array}{l}0.03 \\
(0.01-0.09)\end{array}$ & $\begin{array}{l}0.03 \\
(0.01-0.14)\end{array}$ & $\begin{array}{l}0.04 \\
(0.02-0.09)\end{array}$ & $\begin{array}{l}2.46 \\
(0.32-11.61)\end{array}$ & $\begin{array}{l}0.42 \\
(0.04-2.66)\end{array}$ & $\begin{array}{l}0.18 \\
(0.02-1.64)\end{array}$ & $\begin{array}{l}0.25 \\
(0.02-0.96)\end{array}$ & $\begin{array}{l}0.03 \\
(0.03-1.54)\end{array}$ & $\begin{array}{l}0.03 \\
(0.03-1.39)\end{array}$ & $\begin{array}{l}0.05 \\
(0.05-1.44)\end{array}$ & $\begin{array}{l}1.53 \\
(0.08-10.20)\end{array}$ & $\begin{array}{l}5.76 \\
(2.02-17.91)\end{array}$ \\
\hline 61- & $\begin{array}{l}18 \\
(13.53 \%)\end{array}$ & $\begin{array}{l}0.14 \\
(0.01-0.42)\end{array}$ & $\begin{array}{l}0.02 \\
(0.01-0.08)\end{array}$ & $\begin{array}{l}0.04 \\
(0.01-0.14)\end{array}$ & $\begin{array}{l}0.04 \\
(0.02-0.11)\end{array}$ & $\begin{array}{l}1.67 \\
(0.97-5.08)\end{array}$ & $\begin{array}{l}0.54 \\
(0.05-2.40)\end{array}$ & $\begin{array}{l}0.20 \\
(0.02-2.16)\end{array}$ & $\begin{array}{l}0.28 \\
(0.02-1.93)\end{array}$ & $\begin{array}{l}0.03 \\
(0.03-1.66)\end{array}$ & $\begin{array}{l}0.03 \\
(0.03-1.13)\end{array}$ & $\begin{array}{l}0.05 \\
(0.05-1.64)\end{array}$ & $\begin{array}{l}1.74 \\
(0.38-4.29)\end{array}$ & $\begin{array}{l}6.47 \\
(3.23-11.57)\end{array}$ \\
\hline \multicolumn{15}{|l|}{ Gender } \\
\hline Female & $\begin{array}{l}54 \\
-40.60 \%\end{array}$ & $\begin{array}{l}0.14 \\
(0.01-0.65)\end{array}$ & $\begin{array}{l}0.03 \\
(0.01-0.08)\end{array}$ & $\begin{array}{l}0.03 \\
(0.01-0.14)\end{array}$ & $\begin{array}{l}0.05 \\
(0.03-0.11)\end{array}$ & $\begin{array}{l}1.32 \\
(0.32-4.62)\end{array}$ & $\begin{array}{l}0.34 \\
(0.04-2.40)\end{array}$ & $\begin{array}{l}0.15 \\
(0.02-1.64)\end{array}$ & $\begin{array}{l}0.27 \\
(0.02-1.45)\end{array}$ & $\begin{array}{l}0.03 \\
(0.03-1.66)\end{array}$ & $\begin{array}{l}0.03 \\
(0.03-2.23)\end{array}$ & $\begin{array}{l}0.05 \\
(0.05-1.64)\end{array}$ & $\begin{array}{l}1.43 \\
(0.26-3.97)\end{array}$ & $\begin{array}{l}5.00 \\
(2.02-10.16)\end{array}$ \\
\hline Male & $\begin{array}{l}79 \\
(59.40 \%)\end{array}$ & $\begin{array}{l}0.09 \\
(0.01-0.65)\end{array}$ & $\begin{array}{l}0.03 \\
(0.01-0.09)\end{array}$ & $\begin{array}{l}0.03 \\
(0.01-0.32)\end{array}$ & $\begin{array}{l}0.04 \\
(0.01-0.29)\end{array}$ & $\begin{array}{l}1.61 \\
(0.38-39.46)\end{array}$ & $\begin{array}{l}0.40 \\
(0.02-4.68)\end{array}$ & $\begin{array}{l}0.20 \\
(0.02-2.16)\end{array}$ & $\begin{array}{l}0.25 \\
(0.02-1.93)\end{array}$ & $\begin{array}{l}0.03 \\
(0.03-1.71)\end{array}$ & $\begin{array}{l}0.03 \\
(0.03-2.14)\end{array}$ & $\begin{array}{l}0.05 \\
(0.05-1.74)\end{array}$ & $\begin{array}{l}1.52 \\
(0.08-10.20)\end{array}$ & $\begin{array}{l}5.76 \\
(1.60-45.25)\end{array}$ \\
\hline \multicolumn{15}{|l|}{ Region } \\
\hline Rural & $\begin{array}{l}100 \\
(75.19 \%)\end{array}$ & $\begin{array}{l}0.11 \\
(0.01-0.65)\end{array}$ & $\begin{array}{l}0.03 \\
(0.01-0.09)\end{array}$ & $\begin{array}{l}0.03 \\
(0.01-0.32)\end{array}$ & $\begin{array}{l}0.04 \\
(0.01-0.29)\end{array}$ & $\begin{array}{l}1.34 \\
(0.32-39.46)\end{array}$ & $\begin{array}{l}0.37 \\
(0.02-4.68)\end{array}$ & $\begin{array}{l}0.18 \\
(0.02-2.16)\end{array}$ & $\begin{array}{l}0.27 \\
(0.02-1.91)\end{array}$ & $\begin{array}{l}0.03 \\
(0.03-1.71)\end{array}$ & $\begin{array}{l}0.03 \\
(0.03-2.23)\end{array}$ & $\begin{array}{l}0.05 \\
(0.05-1.64)\end{array}$ & $\begin{array}{l}1.48 \\
(0.08-5.88)\end{array}$ & $\begin{array}{l}5.42 \\
(1.60-45.25)\end{array}$ \\
\hline Urban & $\begin{array}{l}33 \\
(24.81 \%)\end{array}$ & $\begin{array}{l}0.12 \\
(0.01-0.49)\end{array}$ & $\begin{array}{l}0.02 \\
(0.01-0.09)\end{array}$ & $\begin{array}{l}0.03 \\
(0.01-0.08)\end{array}$ & $\begin{array}{l}0.04 \\
(0.03-0.09)\end{array}$ & $\begin{array}{l}1.61 \\
(0.39-17.09)\end{array}$ & $\begin{array}{l}0.36 \\
(0.04-2.14)\end{array}$ & $\begin{array}{l}0.20 \\
(0.02-0.68)\end{array}$ & $\begin{array}{l}0.22 \\
(0.02-1.93)\end{array}$ & $\begin{array}{l}0.03 \\
(0.03-1.66)\end{array}$ & $\begin{array}{l}0.03 \\
(0.03-1.09)\end{array}$ & $\begin{array}{l}0.05 \\
(0.05-1.74)\end{array}$ & $\begin{array}{l}1.46 \\
(0.30-10.20)\end{array}$ & $\begin{array}{l}5.33 \\
(1.74-22.64)\end{array}$ \\
\hline
\end{tabular}




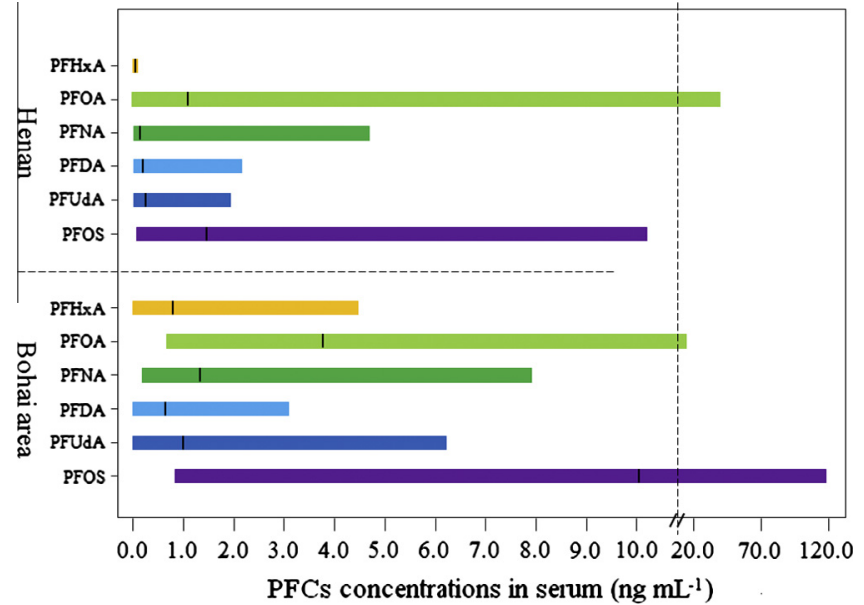

Fig. 1. PFCs concentrations in human serum in Henan from this study, and in cities around the Bohai Sea from previous studies (Guo et al., 2011), in China. Serum data of the Bohai coastal region were transformed from the whole blood data by multiplying a factor of 2 (Kannan et al., 2004). The black vertical lines, left border, and right border of the bars represented median, minimum, and maximum concentrations $\left(\mathrm{ng} \mathrm{mL}^{-1}\right)$ of PFCs, respectively.

PFHxA (76.69\%), PFHpA (98.50\%), PFOA (100.00\%), PFNA (97.74\%), PFDA (82.71\%), PFUdA (81.20\%), PFOS (100.00\%) were detected frequently (>75\%), while PFPeA (63.91\%), PFDoA (34.59\%), PFBS (30.08\%), PFHxS (26.32\%) were found less frequently. Therefore, results for PFPeA, PFDoA, PFBS, and PFHxS are not discussed further.

The median concentration of total PFCs including PFBA, PFPeA, PFHxA, PFHpA, PFOA, PFNA, PFDA, PFUdA, PFDoA and PFOS for 133 serum samples was $5.40 \mathrm{ng} \mathrm{mL}^{-1}$, with a range from 1.60 to $45.25 \mathrm{ng} \mathrm{mL}^{-1}$. PFOS was detected in the greatest median concentration, $1.47 \mathrm{ng} \mathrm{mL}^{-1}$ (range: $0.08-10.20 \mathrm{ng} \mathrm{mL}^{-1}$ ), followed by PFOA at $1.43 \mathrm{ng} \mathrm{mL}^{-1}\left(0.32-39.46 \mathrm{ng} \mathrm{mL}^{-1}\right)$ and PFNA at $0.37 \mathrm{ng} \mathrm{mL}^{-1}(0.02-$ $4.18 \mathrm{ng} \mathrm{mL}^{-1}$ ), and they accounted for about $80 \%$ of the total PFCs.

The median concentrations of PFHxA, PFOA, PFNA, PFDA, PFUdA and PFOS in this study were much less than the concentrations reported earlier from cities around the Bohai Sea (Guo et al., 2011) (Fig. 1). Furthermore, the composition profile of PFCs was quite different between these two areas (Fig. 1). PFOA accounted for $44.06 \%$ of the total PFCs concentrations in Henan whereas in cities around Bohai sea, PFOA only accounted for $19 \%$ of the total PFCs concentrations (Guo et al., 2011). In contrast, PFOS accounted for $25.13 \%$ of the total PFCs concentrations in Henan whereas in cities around Bohai sea, PFOS accounted for $52 \%$ of the total PFCs concentrations (Guo et al., 2011). The differences in concentrations and profile of PFCs between Henan and Bohai suggest different exposure routes in general population between these two areas in China.

There might be two reasons for the large differences of PFCs concentrations between these two areas. Firstly, dietary habits may be one of the reasons for different PFCs concentrations between these two areas. A comparison with intakes of PFCs via other routes suggested that diet is an important source of PFCs (Tittlemier et al., 2007). In coastal areas, the consumption of contaminated seafood is regarded as the main pathway of PFCs exposure (Gulkowska et al., 2006). Individuals with more fish consumption showed higher blood levels of PFCs in Poland (Falandysz et al., 2006). Study of Faroe Islands indicates that whale meat is an important source of PFCs exposure (Weihe et al., 2008). Food such as meat and eggs (Zhang et al., 2010a) had relatively slight PFOS contamination than most seafood. Seafood is also the dominant dietary source for the residents living around the Bohai Sea, and this may explain why those residents have higher PFCs exposures than their counterparts in Henan province.

Secondly, Henan province is a major agricultural province in China, and is less industrialized than Bohai sea area, especially when the individuals in this study were from Yuangyang County, which is one of the most poverty-stricken counties in Henan province. A previous study conducted in the northern China revealed that elevated PFCs concentrations in surface waters were associated with high industrialization levels (Wang et al., 2012). Water source was the primary determinant of serum PFOA concentrations (Emmett et al., 2006). Biomonitoring data showed 4-8 fold higher PFCs concentrations in blood plasma of population exposed to PFCs contaminated drinking water compared with controls (Holzer et al., 2008). These can also explain why the concentrations of PFOS and PFOA in this study were much lower than concentrations from developed countries like USA (Nelson et al., 2010), Japan (Harada et al., 2010) and Germany (Fromme et al., 2009), only higher than those reported for South Africa (Hanssen et al., 2010) and Peru (Calafat et al., 2006b).

Effects of potential determinants on serum PFCs concentrations were shown in Table 2. BMI was significantly associated with PFOA and PFOS concentrations. Meat consumption was positively associated with PFOA concentrations. No significant association of income, egg, fish and seafood consumptions with PFCs concentrations was found. Another study in China also revealed that meat was the primary contributor to dietary exposure to PFOA (Zhang et al., 2010a).

\subsection{Relationships among PFCs}

The Spearman rank correlation coefficients among the different PFCs were examined. Moderate positive correlations were found between PFHpA and PFOS, PFOA and PFOS, PFOA and PFNA, PFOA and PFDA, PFNA and PFDA, PFDA and PFUdA. In general, correlations among various PFCs in the present study were found to be weaker than former reports (Ericson et al., 2007; Pan et al., 2010). The differences in correlation may indicate different exposures. The correlations between PFOA and PFOS $(r=0.219)$ are

Table 2

Linear regression analyses for determinants on serum PFCs concentrations ( $\ln \mathrm{ng} \mathrm{mL}^{-1}$ ).

\begin{tabular}{|c|c|c|c|c|c|c|c|c|c|c|}
\hline & \multicolumn{2}{|c|}{ BMI $\left(\mathrm{kg} \mathrm{m}^{-2}\right)$} & \multicolumn{2}{|c|}{ Income (CNY) } & \multicolumn{2}{|c|}{ Meat (days week ${ }^{-1}$ ) } & \multicolumn{2}{|c|}{ Egg (days week ${ }^{-1}$ ) } & \multicolumn{2}{|c|}{ Fish and seafood (days week ${ }^{-1}$ ) } \\
\hline & $\beta$ & $95 \% \mathrm{CI}$ & $\beta$ & $95 \% \mathrm{CI}$ & $\beta$ & $95 \% \mathrm{CI}$ & $\beta$ & $95 \% \mathrm{CI}$ & $\beta$ & $95 \% \mathrm{CI}$ \\
\hline PFBA & -0.036 & $(-0.094,0.022)$ & -0.064 & $(-0.335,0.207)$ & 0.004 & $(-0.300,0.308)$ & 0.211 & $(-0.095,0.516)$ & 0.110 & $(-0.296,0.515)$ \\
\hline PFHxA & -0.029 & $(-0.063,0.005)$ & 0.033 & $(-0.127,0.193)$ & 0.008 & $(-0.171,0.188)$ & -0.034 & $(-0.214,0.146)$ & 0.206 & $(-0.033,0.444)$ \\
\hline PFHpA & -0.011 & $(-0.030,0.007)$ & -0.016 & $(-0.103,0.072)$ & -0.024 & $(-0.122,0.074)$ & -0.045 & $(-0.144,0.053)$ & -0.047 & $(-0.178,0.084)$ \\
\hline PFOA & $0.063^{\mathrm{b}}$ & $(0.027,0.098)$ & -0.035 & $(-0.203,0.133)$ & $0.198^{\mathrm{a}}$ & $(0.010,0.386)$ & 0.166 & $(-0.023,0.355)$ & 0.004 & $(-0.247,0.255)$ \\
\hline PFNA & 0.031 & $(-0.011,0.073)$ & -0.027 & $(-0.224,0.170)$ & 0.136 & $(-0.084,0.357)$ & -0.030 & $(-0.252,0.192)$ & 0.092 & $(-0.202,0.386)$ \\
\hline PFDA & 0.010 & $(-0.045,0.065)$ & -0.016 & $(-0.275,0.244)$ & 0.091 & $(-0.200,0.382)$ & -0.215 & $(-0.077,0.507)$ & -0.034 & $(-0.422,0.353)$ \\
\hline PFUdA & 0.054 & $(-0.003,0.111)$ & -0.013 & $(-0.280,0.255)$ & -0.058 & $(-0.359,0.242)$ & -0.066 & $(-0.367,0.236)$ & 0.034 & $(-0.367,0.434)$ \\
\hline PFOS & $0.040^{\mathrm{a}}$ & $(0.011,0.069)$ & -0.009 & $(-0.145,0.128)$ & 0.059 & $(-0.095,0.212)$ & 0.019 & $(-0.135,0.172)$ & 0.099 & $(-0.105,0.304)$ \\
\hline
\end{tabular}

\footnotetext{
a $p<0.05$.
}

b $p<0.01$. 

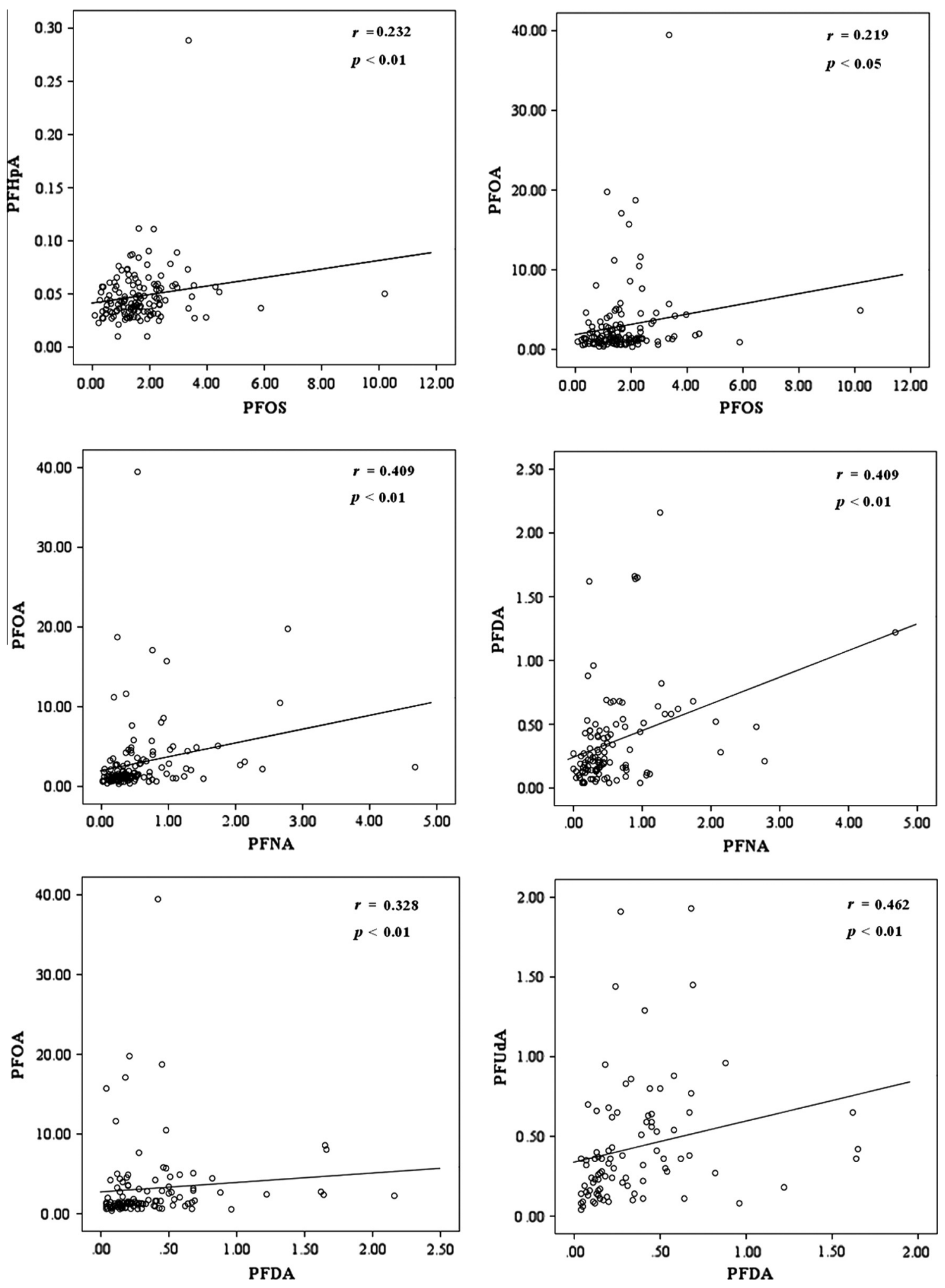

Fig. 2. Significant correlations found among different PFCs.

meaningful because they are the end stage products of the degradation of their precursors, and cannot be converted into each other (Kannan et al., 2004). Therefore, it means common sources for human exposure of these two PFCs classes in daily life. The regression analysis of the associations between Spearman's correlated PFCs concentrations in serum samples of 133 donors from Yuanyang County is shown in Fig. 2.
In addition, the Spearman rank correlation coefficients among the different PFCs in different age, gender, and region groups were also examined. Most of the correlations found in subgroups, except urban group, were consistent with their counterparts in the whole group. The correlation between PFOA and PFOS was no longer significant $(p=0.089)$ in urban group (see Supplementary Table S3). It was assumed that urban residents might contact more frequently 
with various products that contain PFCs and have more complicated exposure pathways of PFCs than rural residents.

\subsection{Age effect on PFCs concentrations}

Studies were not always consistent in terms of age effect on PFCs concentrations. Significant correlations of serum PFCs with age were reported in some studies (Holzer et al., 2008; Haug et al., 2009; Zhang et al., 2010b). In a Chinese study, the concentration of PFOS increased significantly with age, while PFOA concentration showed a negative correlation with age (Zhang et al., 2010b). Significant positive correlations between PFOA, PFOS and age were reported by Holzer et al. (2008). Haug et al. (2009) reported that PFNA, PFDA, and PFUdA concentrations in serum increased with age. In contrast, in the NHANES study, in which 54 pooled serum samples of the 2001/2002 survey and 1562 serum samples of the 1999-2000 survey were analyzed, no association of PFCs concentrations with age was found (Calafat et al., 2006a; Calafat et al., 2007). Studies on a Chinese population around Bohai sea did not show any significant difference between two age groups (Guo et al., 2011). The inconsistent results of age effect on PFCs in human serum may be attributable to a large number of parameters such as chemical half-life, elimination, occupation, lifestyle, and some physiological factors (Karrman et al., 2006).

In this study, concentrations for each compound in the different age groups are given in Table 1 . For all donors ( $0-88$ years), significant increases in PFOA $(r=0.239, p<0.01)$, PFNA $(r=0.185$, $p<0.05)$ and PFOS $(r=0.175, p<0.05)$ concentrations with age were found; No significant association between age and other PFCs was found (Supplementary Table S4). PFOA was consistently correlated with age in all five age groups (Supplementary Table S5). Furthermore, the PFOA concentrations of both regions showed significant positive correlations with age; the PFOA and PFNA concentrations of males showed significant positive correlations with age, while no PFCs concentrations of females was found significantly correlated with age (Supplementary Table S4), which can be attributable to possible excretion ways for females, e.g., menstrual bleeding, pregnancy and lactation (Harada et al., 2005; Karrman et al., 2007).

\subsection{Gender effect on PFCs concentrations}

The concentrations for each PFC in the serum samples stratified by gender are given in Table 1 . Median concentrations of PFOA, PFNA, PFDA, and PFOS appeared to be higher in males than in females across all ages (Table 1 ), although the differences were only statistically significant for PFOA $(p<0.01)$ and PFDA $(p<0.05)$ by using Mann-Whitney $U$ test. Gender differences in concentrations of PFBA, PFHxA, PFHpA and PFUdA were not obvious. Detailed Mann-Whitney results of gender differences cound be found in Supplementary Materials Table S6. Higher concentrations of PFCs in males compared to females have been reported previously in China (Guo et al., 2011; Zhang et al., 2011), in USA (Calafat et al., 2007), in Germany (Fromme et al., 2007), and in Australia (Karrman et al., 2006).

Gender differences in PFCs concentrations may be attributed to differences in exposure or pharmacokinetic reasons (Calafat et al., 2007) although these are yet to be elucidated. PFCs were detected in maternal serum and milk (Karrman et al., 2007; Tao et al., 2008), thus pregnancy and lactation in females are possible routes for PFCs excretion. Menstrual bleeding is also hypothesized as a possible elimination route for premenopausal females (Harada et al., 2005). These were supported by the outcome showed in Fig. 3. PFOA and PFOS concentrations, which account for about $70 \%$ of total PFCs concentrations, were significantly higher in males than in females in population aged from 16 to 60 years; while in population younger than 15 and older than 60 , there were no significant difference between two genders. Thus total PFCs showed the same trend although PFHpA showed the opposite trend and other PFCs showed no significant trends.

\subsection{Region effect on PFCs concentrations}

Studies were controversial in terms of the region effect on PFCs concentrations. No statistically significant difference was found in PFCs concentrations between rural and urban regions in an Australia study (Karrman et al., 2006), while higher PFOS and PFOA concentrations in urban areas compared to rural areas could be seen in Japan and Sri Lanka (Harada et al., 2004; Guruge et al., 2005). Another study conducted in Germany reported that PFOA concentrations were significantly decreased in urban populations comparing to populations living in the rural area, but there was no significant difference in PFOS concentrations between urban and rural populations (Fromme et al., 2007). In this study, statistically significant difference could only be found in PFOA concentrations between the two regions. Higher PFOA concentrations were found in urban populations. This may be attributed to the different dietary habits between urban and rural populations. Mann-Whitney $U$ test on possible determinants of PFCs exposures showed that meat consumption frequency of urban residents was significantly higher than their rural counterparts. In addition, results from linear regression analyses revealed that meat consumption was positively associated with PFOA concentrations. These may explain the reason why higher PFOA concentrations were found in urban populations.

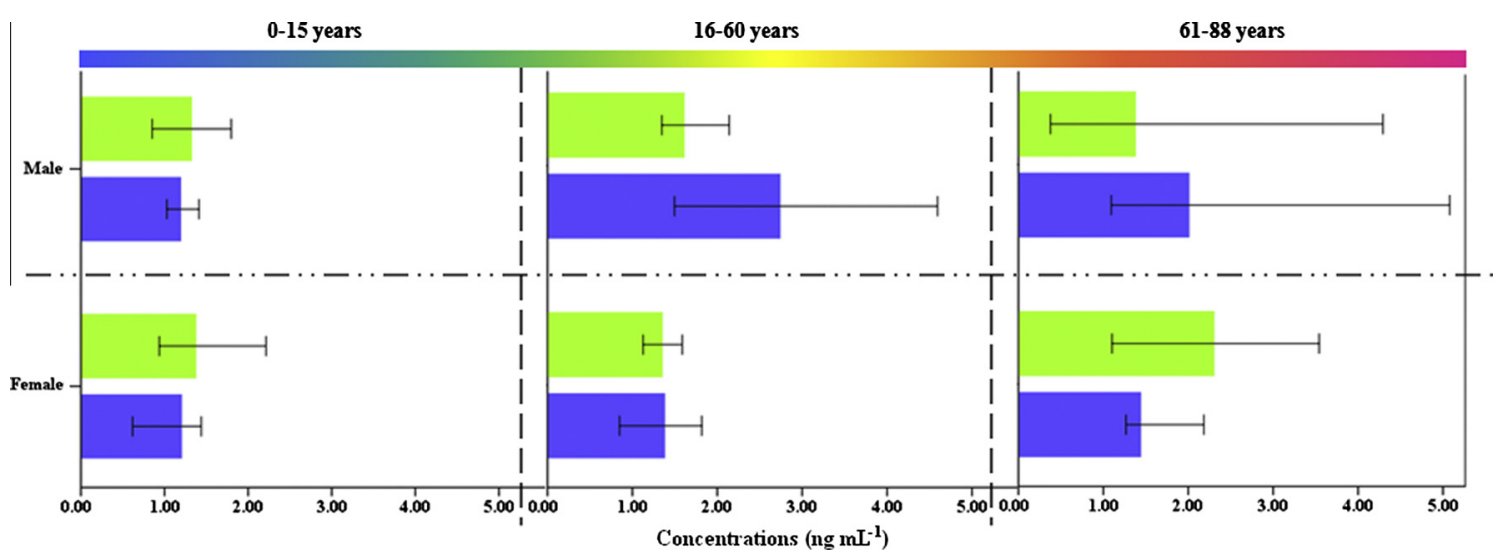

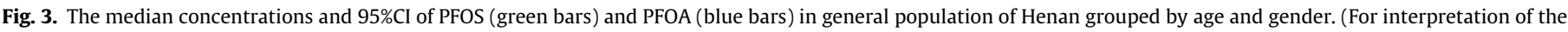
references to colour in this figure legend, the reader is referred to the web version of this article.) 


\section{Conclusions}

In summary, the results from this study indicate that human exposure to PFCs, although at a low level, is prevalent in general population of Henan, China. Among the 12 target PFCs, PFOA and PFOS were the major compounds, which accounted for $69.19 \%$ of the total PFCs. Age was positively correlated with PFOA, PFNA, and PFOS concentrations. Median concentrations of PFOA, PFNA, PFDA, and PFOS were higher in males than in females. In addition, higher PFOA concentrations were found in urban populations than in rural populations. It is suggested that the general population is exposed to different sources of PFCs. Since PFCs exposure in general population is ubiquitous, further studies on relationships among epidemiological factors and PFCs exposure are needed.

\section{Acknowledgments}

We are grateful to the staff of The Red Cross Hospital in Yuanyang County (Henan, China) for serum collection. We gratefully acknowledge all the donors for their collaboration and blood donation. This study was supported by the National Natural Science Foundation of China under Grant No.41371488 and No. 41071355, the International Scientific Cooperation Program with Grant No. 2012DFA91150, and the Key Project of the Chinese Academy of Sciences under Grant No.KZZD-EW-TZ-12. We would like to thank the editors and reviewers for their valuable comments and suggestions.

\section{Appendix A. Supplementary material}

Supplementary data associated with this article can be found, in the online version, at http://dx.doi.org/10.1016/j.chemosphere. 2014.02.020.

\section{References}

Bao, J., Liu, W., Liu, L., Jin, Y., Dai, J., Ran, X., Zhang, Z., Tsuda, S., 2011. Perfluorinated Compounds in the Environment and the Blood of Residents Living near Fluorochemical Plants in Fuxin, China. Environ. Sci. Technol. 45, 8075-8080.

Calafat, A.M., Kuklenyik, Z., Caudill, S.P., Reidy, J.A., Needham, L.L., 2006 a. Perfluorochemicals in pooled serum samples from United States residents in 2001 and 2002. Environ. Sci. Technol. 40, 2128-2134.

Calafat, A.M., Kuklenyik, Z., Reidy, J.A., Caudill, S.P., Tully, J.S., Needham, L.L., 2007. Serum concentrations of 11 polyfluoroalkyl compounds in the US population: Data from the National Health and Nutrition Examination Survey (NHANES) 1999-2000. Environ. Sci. Technol. 41, 2237-2242.

Calafat, A.M., Needham, L.L., Kuklenyik, Z., Reidy, J.A., Tully, J.S., Aguilar-Villalobos, M., Naeher, L.P., 2006b. Perfluorinated chemicals in selected residents of the American continent. Chemosphere 63, 490-496.

Emmett, E.A., Shofer, F.S., Zhang, H., Freeman, D., Desai, C., Shaw, L.M., 2006 Community exposure to perfluorooctanoate: Relationships between serum concentrations and exposure sources. J. Occup. Environ. Med. 48, 759-770.

Ericson, I., Gomez, M., Nadal, M., van Bavel, B., Lindstrom, G., Domingo, J.L., 2007. Perfluorinated chemicals in blood of residents in Catalonia (Spain) in relation to age and gender: A pilot study. Environ. Int. 33, 616-623.

Falandysz, J., Taniyasu, S., Gulkowska, A., Yamashita, N., Schulte-Oehlmann, U. 2006. Is fish a major source of fluorinated surfactants and repellents in humans living on the Baltic coast? Environ. Sci. Technol. 40, 748-751.

Fromme, H., Midasch, O., Twardella, D., Angerer, J., Boehmer, S., Liebl, B., 2007. Occurrence of perfluorinated substances in an adult German population in southern Bavaria. Int. Arch. Occup. Environ. Health 80, 313-319.

Fromme, H., Tittlemier, S.A., Volkel, W., Wilhelm, M., Twardella, D., 2009. Perfluorinated compounds - Exposure assessment for the general population in western countries. Int. J. Hyg. Environ. Health 212, 239-270.

Giesy, J.P., Kannan, K., 2001. Global distribution of perfluorooctane sulfonate in wildlife. Environ. Sci. Technol. 35, 1339-1342.

Gulkowska, A., Jiang, Q.T., So, M.K., Taniyasu, S., Lam, P.K.S., Yamashita, N., 2006. Persistent perfluorinated acids in seafood collected from two cities of China. Environ. Sci. Technol. 40, 3736-3741.

Guo, F., Zhong, Y., Wang, Y., Li, J., Zhang, J., Liu, J., Zhao, Y., Wu, Y., 2011. Perfluorinated compounds in human blood around Bohai Sea, China. Chemosphere 85, 156-162.

Guruge, K.S., Taniyasu, S., Yamashita, N., Wijeratna, S., Mohotti, K.M., Seneviratne, H.R., Kannan, K., Yamanaka, N., Miyazaki, S., 2005. Perfluorinated organic compounds in human blood serum and seminal plasma: a study of urban and rural tea worker populations in Sri Lanka. J. Environ. Monit. 7, 371-377.
Hansen, K.J., Clemen, L.A., Ellefson, M.E., Johnson, H.O., 2001. Compound-specific, quantitative characterization of organic: Fluorochemicals in biological matrices. Environ. Sci. Technol. 35, 766-770.

Hanssen, L., Roellin, H., Odland, J.O., Moe, M.K., Sandanger, T.M., 2010 Perfluorinated compounds in maternal serum and cord blood from selected areas of South Africa: results of a pilot study. J. Environ. Monit. 12, 1355-1361.

Harada, K., Inoue, K., Morikawa, A., Yoshinaga, T., Saito, N., Koizumi, A., 2005. Renal clearance of perfluorooctane sulfonate and perfluorooctanoate in humans and their species-specific excretion. Environ. Res. 99, 253-261.

Harada, K., Saito, N., Inoue, K., Yoshinaga, T., Watanabe, T., Sasaki, S., Kamiyama, S. Koizumi, A., 2004. The influence of time, sex and geographic factors on levels of perfluorooctane sulfonate and perfluorooctanoate in human serum over the last 25 years. J. Occup. Health 46, 141-147.

Harada, K.H., Yang, H.R., Moon, C.S., Hung, N.N., Hitomi, T., Inoue, K., Niisoe, T., Watanabe, T., Kamiyama, S., Takenaka, K., Kim, M.Y., Watanabe, K., Takasuga, T., Koizumi, A., 2010. Levels of perfluorooctane sulfonate and perfluorooctanoic acid in female serum samples from Japan in 2008, Korea in 1994-2008 and Vietnam in 2007-2008. Chemosphere 79, 314-319.

Haug, L.S., Thomsen, C., Bechert, G., 2009. Time trends and the influence of age and gender on serum concentrations of perfluorinated compounds in archived human samples. Environ. Sci. Technol.. 43, 2131-2136.

Holzer, J., Midasch, O., Rauchfuss, K., Kraft, M., Reupert, R., Angerer, J., Kleeschulte P., Marschall, N., Wilhelm, M., 2008. Biomonitoring of perfluorinated compounds in children and adults exposed to perfluorooctanoatecontaminated drinking water. Environ. Health Perspect. 116, 651-657.

Kannan, K., Corsolini, S., Falandysz, J., Fillmann, G., Kumar, K.S., Loganathan, B.G., Mohd, M.A., Olivero, J., Van Wouwe, N., Yang, J.H., Aldous, K.M., 2004 Perfluorooctanesulfonate and related fluorochemicals in human blood from several countries. Environ. Sci. Technol. 38, 4489-4495.

Karrman, A., Ericson, I., van Bavel, B., Darnerud, P.O., Aune, M., Glynn, A., Lignell, S. Lindstrom, G., 2007. Exposure of perfluorinated chemicals through lactation: Levels of matched human milk and serum and a temporal trend, 1996-2004, in Sweden. Environ. Health Perspect. 115, 226-230.

Karrman, A., Mueller, J.F., Van Bavel, B., Harden, F., Toms, L.M.L., Lindstrom, G., 2006 Levels of 12 perfluorinated chemicals in pooled Australian serum, collected 2002-2003, in relation to age, gender, and region. Environ. Sci. Technol. 40, $3742-3748$.

Lau, C., Anitole, K., Hodes, C., Lai, D., Pfahles-Hutchens, A., Seed, J., 2007 Perfluoroalkyl acids: a review of monitoring and toxicological findings. Toxicol. Sci. 99, 366-394.

Martin, J.W., Whittle, D.M., Muir, D.C.G., Mabury, S.A., 2004. Perfluoroalkyl contaminants in a food web from lake Ontario. Environ. Sci. Technol. 38, 5379-5385.

Meesters, R.J.W., Schroder, H.F., 2004. Perfluorooctane sulfonate - a quite mobile anionic anthropogenic surfactant, ubiquitously found in the environment. Water Sci. Technol. 50, 235-242.

Nelson, J.W., Hatch, E.E., Webster, T.F. 2010. Exposure to polyfluoroalkyl chemicals and cholesterol, body weight, and insulin resistance in the general US population. Environ. Health Perspect. 118, 197-202.

Pan, Y., Shi, Y., Wang, J., Cai, Y., Wu, Y., 2010. Concentrations of perfluorinated compounds in human blood from twelve cities in China. Environ. Toxicol. Chem. 29, 2695-2701.

Shoeib, M., Harner, T., Wilford, B.H., Jones, K.C., Zhu, J.P., 2005. Perfluorinated sulfonamides in indoor and outdoor air and indoor dust: occurrence, partitioning, and human exposure. Environ. Sci. Technol. 39, 6599-6606.

Skutlarek, D., Exner, M., Farber, H., 2006. Perfluorinated surfactants in surface and drinking water. Environ. Sci. Pollut. R 13, 299-307.

So, M.K., Yamashita, N., Taniyasu, S., Jiang, O.T. Giesy, J.P. Chen, K., Lam, P.K.S., 2006 Health risks in infants associated with exposure to perfluorinated compounds in human breast milk from Zhoushan, China. Environ. Sci. Technol. 40, 2924-2929.

Tao, L. Kannan, K., Wong, C.M., Arcaro, K.F., Butenhoff, J.L, 2008, Perfluorinated compounds in human milk from Massachusetts, USA. Environ Sci Technol 42, 3096-3101.

Tittlemier, S.A., Pepper, K., Edwards, L., 2006. Concentrations of perfluorooctanesulfonamides in Canadian total diet study composite food samples collected between 1992 and 2004. J. Agric. Food Chem. 54, 8385-8389.

Tittlemier, S.A., Pepper, K., Seymour, C., Moisey, J., Bronson, R., Cao, X.-L., Dabeka, R.W., 2007. Dietary exposure of Canadians to perfluorinated carboxylates and perfluorooctane sulfonate via consumption of meat, fish, fast foods, and food items prepared in their packaging. J. Agric. Food Chem. 55, 3203-3210.

Wang, T.Y., Khim, J.S., Chen, C.L., Naile, J.E., Lu, Y.L., Kannan, K., Park, J., Luo, W., Jiao, W.T., Hu, W.Y.,Giesy, J.P., 2012. Perfluorinated compounds in surface waters from Northern China: comparison to level of industrialization. Environ. Int. 42, 37-46.

Weihe, P., Kato, K., Calafat, A.M., Nielsen, F., Wanigatunga, A.A., Needham, L.L. Grandjean, P., 2008. Serum concentrations of polyfluoroalkyl compounds in Faroese whale meat consumers. Environ. Sci. Technol. 42, 6291-6295.

Zhang, T., Sun, H.W., Wu, Q., Zhang, X.Z., Yun, S.H., Kannan, K., 2010a. Perfluorochemicals in meat, eggs and indoor dust in China: assessment of sources and pathways of human exposure to perfluorochemicals. Environ. Sci. Technol. 44, 3572-3579.

Zhang, T., Wu, Q., Sun, H.W., Zhang, X.Z., Yun, S.H., Kannan, K., 2010b. Perfluorinated compounds in whole blood samples from infants, children, and adults in China. Environ. Sci. Technol. 44, 4341-4347.

Zhang, W., Lin, Z., Hu, M., Wang, X., Lian, Q., Lin, K., Dong, Q., Huang, C., 2011. Perfluorinated chemicals in blood of residents in Wenzhou, China. Ecotoxicol Environ. Saf. 74, 1787-1793. 